\title{
SOIL QUALITY ATTRIBUTES RELATED TO URBANIZATION IN BRAZILIAN WATERSHED
}

\author{
Alexandre Marco da SILVAa, Rodrigo Custodio URBAN ${ }^{\mathrm{b}}$, Luiz Augusto MANFRÉc, \\ Michel BROSSARD ${ }^{\mathrm{d}}$, Marcelo Zacharias MOREIRA ${ }^{\mathrm{e}}$ \\ ${ }^{a}$ Department of Environmental Engineering, Campus Sorocaba, São Paulo State University, \\ Av. Três de Março 511, Sorocaba, SP, Brazil \\ ${ }^{b}$ Department of Sanitation and Environment, FEC, Campinas State University, \\ Av. Albert Einstein, 951, Campinas, SP, Brazil \\ ${ }^{c}$ Geoprocessing Laboratory, Polytechnic School, University of São Paulo, \\ Avenue Professor Luciano Gualberto, Lane 3, 380 São Paulo, Brazil \\ ${ }^{d}$ IRD, UMR 210 EcođSols, BP 64501, 34394 Montpellier cedex 5, France \\ ${ }^{e}$ Centre for Nuclear Energy in Agriculture, University of São Paulo, Av. Centenário, 303 - Piracicaba, SP, Brazil \\ Submitted 12 Jan. 2015; accepted 14 Feb 2017

\begin{abstract}
In this study we investigated the variation of soil attributes according to urban-related land cover categories. The study was carried out in an urbanized watershed located in the Brazilian subtropical region (Sorocaba Municipality, São Paulo). Soil samples were collected considering the land cover category for analysis of physical, chemical and isotopic attributes. The land cover influenced the soils attributes. Soils from wooded and grassed areas presented significant differences, especially for values of $\mathrm{C}$ isotopes. Soil bulk density was significantly altered. According to considered land cover mosaic in the study, we estimated 10,241.28 tons of C stored in the thickness $20 \mathrm{~cm}$ of the watershed (whole area), and this amount is almost a half of the total potential of $\mathrm{C}$ storing in the watershed. We stress that projects of planned land cover should effectively implemented in urbanized regions to effectively contribute in storing more $\mathrm{C}$ and improving the soil-related ecosystem services.
\end{abstract}

Keywords: environmental impact assessment, environmental sustainability, landscape management.

\section{Introduction}

Soils are a critical component of any terrestrial ecosystem and they have both inherent and dynamic properties that may vary according to regional physiographic features. However, human activities also alter the soil properties of many forms. Such alterations, usually degrading, have getting more and more importance over the time due the impoverishment of the soil quality (Alberti 2005). The establishment and the expansion of urban areas, when poorly designed, is an anthropogenic activity that expressively alters the original characteristics of the soils (Kahan 2008; Pickett, Cadenasso 2009; Hagan et al. 2012).

Urbanization is a human-induced process that has social, economic and environmental causes and implications (UN 2014). Urbanization frequently produces alterations in land cover (De Kimpe, Morel 2000; Scalenghe, Marsan 2009; Edmondson et al. 2011), usually resulting in a landscape characterized by mosaic of land cover patterns (Antrop 2004; Alphan, Güvensoy 2016).

One of the main factors that drive the quality of soil organic matter (SOM) is the kind of organic material that is deposited on the soil surface and that is slowly incorporated into the soil profile (Lorenz, Lal 2009). The modification of the land cover normally modifies the kind of organic material that is deposited on the soil surface and, consequently, changes the quality of SOM. Because of the process of land cover shifting, the native vegetation usually is removed and new species that might not otherwise co-exist, including exotic plant species, are inserted in the "new" environment, modifying many soil attributes and degrading the quality (Alberti 2005). Modifying the SOM signifies changing parts of the cycles of both carbon (C) and nitrogen (N) (Pouyat et al. 2006; Baltrenas et al. 2010) and such alterations are proved through analysis of the

Corresponding author: Alexandre Marco da Silva

E-mail: amsilva@sorocaba.unesp.br 
stable isotopes of the $\mathrm{C}$ and $\mathrm{N}$ of the soil organic matter (Norra et al. 2005; Boeckx et al. 2006; Kaye et al. 2006).

Several urban-related activities voluntarily or involuntarily compact the soil. Compaction of the soil leads to increased bulk density (BD), and the BD usually becomes greater than natural areas, prejudicing, for example the soil porosity and water infiltration (Scharenbroch et al. 2005; Hagan et al. 2012). When the soil clods are getting more disaggregated, the porosity diminishes and the rates of soil loss caused by the rain-induced erosive process tend to augment. The erosion process plays an important role in the chemical impoverishment of the soil, which might signify diminution of concentration of some extractable elements in the soil (Morgan 2009), evaluated by means of analyses of the cation exchange capacity (CEC) or also the electrical conductivity (EC). EC is a measure relatively easy and cheap to be made and gives the idea of the soluble salts present in the soil (Seifi et al. 2010). Some forms of soil pollution trend to increasing the EC values (Saritha et al. 2014), while others, especially erosion-related problems, diminish the values of EC (Silva et al. 2015a).

Considering the effects of urbanization in the assessment of the budget of $\mathrm{C}$ in localities and regions that experience rapid urban expansions is of high importance, since there is the chance of identify hotspots of gains and losses of C (Jim 1998; Pouyat et al. 2002, 2006; Tao et al. 2014).

In the region of the Latin American continent the number of people living in urban areas has increased rapidly and the soils have been modified and converted into "Technosols". Currently 79\% of the total population from Latin American continent and 85\% from Brazilian territory live in urban areas (WB 2014). This urban swelling has happening without a suitable planning. Conversely, few studies have been developed in the urbanized areas of the Latin American continent in order to report aspects of the transformations in the soils of urban regions and related data are still meager.

Exemplifying, in a world context, there is a lot of papers regarding alterations of soil properties due the urbanization process, as Jim (1998) for Hong Kong; Norra et al. (2005) for Karlsruhe (Germany); Boeckx et al. (2006) for Gent (Belgium), Hagan et al. (2012) for Tampa (FL, USA) and/or by Wang et al. (2013) for Shanghai (China). However, for regions of Latin American continent, few papers are found. The papers published by Barrales et al. (2007) and Vela Correa et al. (2012) for Mexico City; Moura et al. (2006) for Teresina City (Capital City of Piauí State, Northeast Brazil); and López et al. (2006) for Buenos Aires (Argentina) are the main ones published. This characterizes a lack information and knowledge regarding biogeochemical mechanisms that happen in urban soils from Latin America and a high demand for new studies.

Hence, in this study we investigated the variation of the quality of soil and SOM attributes for land cover classes generated by the urbanization. We hypothesized that land cover change towards the urbanization provokes alteration in the soil properties. However, we do not know if the alterations in the region focused on this study the soils are similar to alterations reported in other regions (continents), in terms of typology and magnitude. Here we did not investigate the consequences of urbanization over time, but instead we focused on the effects of urbanization in a spatial context. Furthermore, because of the data regarding chemical and physical attributes in urban soils from Latin America are scarce; this paper constitutes a baseline to be compared with the later acquired information in urban soils from such region.

\section{Location and environmental characteristics of study area}

The watershed that attended the desired conditions for our investigation was one that lies on Sorocaba Municipality (Fig. 1). Sorocaba has $449 \mathrm{~km}^{2}$ and about 629,000 inhabitants, being approximately $98 \%$ urban (IBGE 2013). The investigated watershed encompasses 277 hectares and has an average density of 3,000 inhabitants per $\mathrm{km}^{2}$. Soil surface is predominantly impervious by asphalt or concrete. There is no highways or hard traffic avenues, but there is permanent traffic of cars, buses and small trucks. Land use is mainly for residential ends, with some small commercial establishments, as well as educational institutions. Grassy areas (or pasture) usually occur in places where the land use is less intense as in gardens and vacant lots. In such grassy areas there is no livestock. Brachiaria grass (Brachiaria decumbens, Stapf) is the main grass species that occurs along the grassy areas.

Summers are rainy and hot, whereas the winters are slight and dry. Annual average temperature is $21.4^{\circ} \mathrm{C}$. Annual rainfall depth is $1,309 \mathrm{~mm}$. Regional relief is predominantly slight-waved. Bedrock is sedimentary and a significant portion is constituted by fine- to medium-grained sandstones (IGSP 2009). Soils are deep, mostly brown, with very low or null stoniness, and they are predominantly sandy loams and slightly acids. The original class is Ferralsols (Melfi et al. 2004). Cultivated, irrigated and/ or fertilized lots do not take place along the watershed. In addition, neither lentic aquatic environments, nor landfills occur. Some earthworks are observed and they have the goal to adequacy of the topography of some places for residential constructions.

The original vegetation formation in the region was an ecotonal belt constituted by Atlantic Rain Forest (semideciduous forest) and Brazilian Savanna (Kronka et al. 2005). Most of the original vegetation has been removed for establishment of residential districts (houses in towns). Fire sometimes occurs in the region on dry seasons (July and August) and it usually occurs in grassy and/or wooded 


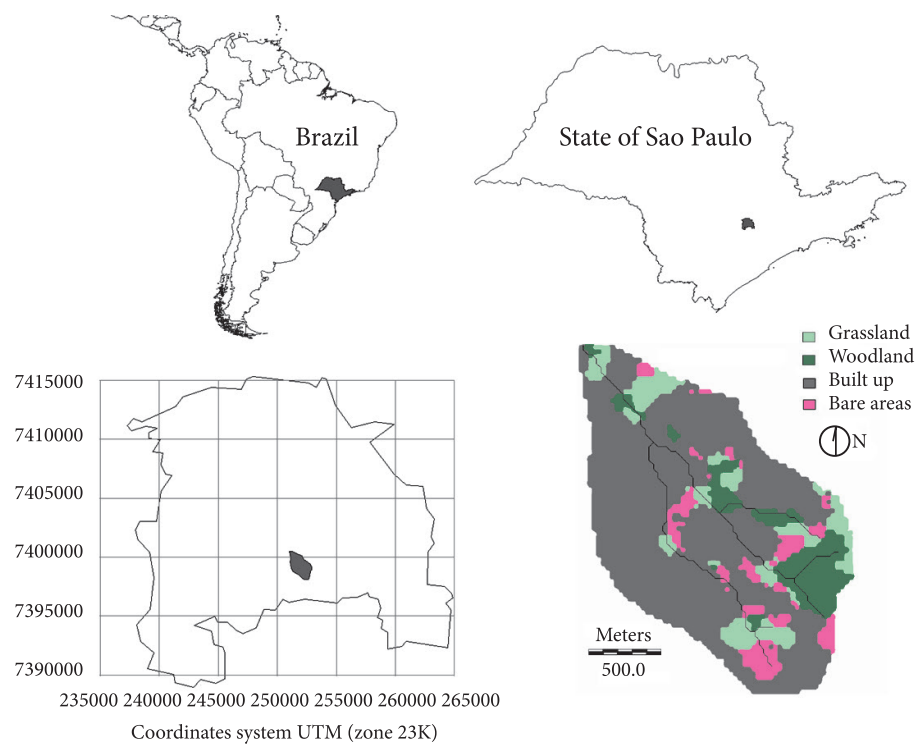

Fig. 1. Upper left: Brazilian states (highlighting State of Sao Paulo). Upper right: Boundaries of State of Sao Paulo (highlighting Sorocaba). Bottom left: Boundaries of Sorocaba (highlighting the studied watershed). Bottom right: Land cover map of studied map (modified from Silva 2012)

Table 1. Land cover categories considered for study, percentage of occurrence, brief characterization of each land cover category and number of soil samples taken in each land cover category (source: modified from Anderson 1976)

\begin{tabular}{llc}
\hline $\begin{array}{c}\text { Land cover class } \\
\text { and percentage of } \\
\text { occurrence }\end{array}$ & \multicolumn{1}{c}{ Characterization } & $\begin{array}{c}\text { Number of soil samples collected } \\
\text { according to each class of land cover } \\
(\mathrm{N}=40)\end{array}$ \\
\hline Woodland (10.7) & Small forest remnant patches in distinct degrees of conservation & 10 \\
\hline Grassland (11.6) & $\begin{array}{l}\text { Lawned areas covered with invasive grass and with distinct } \\
\text { levels of conservation, usually occurring in vacant lots }\end{array}$ & 10 \\
\hline $\begin{array}{l}\text { Bare areas } \\
(8.2)\end{array}$ & $\begin{array}{l}\text { Areas with the soils poorly covered/protected, where soil } \\
\text { exposure is clearly visible, typically used as domestic or public } \\
\text { greenspaces }\end{array}$ & 11 \\
\hline & $\begin{array}{l}\text { Urban or Built-up land is comprised of areas of intensive use } \\
\text { with much of the land covered by structures. Also normally } \\
(69.5)\end{array}$ & $\begin{array}{l}\text { used as domestic or public greenspaces. They are private } \\
\text { or public properties/places of various sizes, usually using } \\
\text { decorative lawns in gardens of various sizes }\end{array}$ \\
\hline
\end{tabular}

sites. Currently, forested areas are reduced and scattered, with various levels of conservation. Some forest patches are riparian vegetation (Silva et al. 2013). The land cover categories were distinguished and identified according to USGS classification system (Anderson 1976). Table 1 provides specific information about each land cover class.

\section{Procedures}

\subsection{Field sampling design and laboratorial analyses}

Soil samples were taken following the land cover categories, aiming to capture the spatial heterogeneity of land cover (Vasenev et al. 2013). Forty undisturbed soil samples were collected throughout the watershed according to the occurrence of the four land cover categories.

All sampling points (henceforward SP) were georreferenced and they were always located at least 4 meters away from any fence lines to avoid possible edge effects
(Silva 2012). They were collected in a thickness of $0-20 \mathrm{~cm}$ of soil, using a stainless steel cylinder (volume of $254 \mathrm{~cm}^{3}$ ). In the laboratory soil samples were oven-dried and weighted at $80{ }^{\circ} \mathrm{C}$. The soil bulk density, i.e., the mass of a soil sample in a known volume (Jim 1998), was determined for each sample. Next, the samples were manually crushed and subdivided into three subsamples (Urban 2011). The first and second subsamples were sieved separately (both in mesh $2.00 \mathrm{~mm}$ ) and the fraction $<2.00 \mathrm{~mm}$ of the $1^{\text {st }}$ subsample was delivered to Laboratory of Soil Analyses of Esalq - USP (Piracicaba, SP, Brazil) for analyzes of the sand fractions (coarse, medium and fine), silt and clay contents (Raij et al. 2001) and the Cation Exchange Capacity (CEC) (Ruggiero et al. 2002). The fraction of the $2^{\text {nd }}$ subsample $<2.00 \mathrm{~mm}$ was used for analyses of $\mathrm{pH}\left(\mathrm{H}_{2} \mathrm{O}\right)$ and electrical conductivity (EC). For $\mathrm{pH}$ and EC analyses, $30 \mathrm{ml}$ of soil were mixed with $75 \mathrm{ml}$ of distilled water in a glass beaker. After 30 minutes from the 
last agitation (Raij et al. 2001) and using a probe multi-parameter Oakton model PCS Test 35 previously calibrated, we measured the $\mathrm{pH}$ and the EC.

The $3^{\text {rd }}$ subsample was also sieved (mash of $0.35 \mathrm{~mm}$ ), and the portion $<0.35 \mathrm{~mm}$ was sent to Laboratory of Isotopic Ecology of CENA-USP (Piracicaba, SP, Brazil) for quantification of the concentrations of $\mathrm{C}$ and $\mathrm{N}$ and their respective isotopic signatures. These determinations were done through gas chromatography after sample burning in an oxidant medium, by a Carlo Erba 1110 elemental analyzer conjugated to a Thermo Scientific Delta Plus isotopic ratio mass spectrometer.

The isotopic signatures of $\mathrm{C}$ and $\mathrm{N}$ were estimated using the Eq. (1) (Farquhar et al. 1989):

$$
\delta^{13} \mathrm{C}\left(\text { or } \delta^{15} \mathrm{~N}\right)=\left[\left(R_{s a}-R_{s t}\right) R_{s t}^{-1}\right] 1000,
$$

where $\delta^{13} \mathrm{C}$ (or $\delta^{15} \mathrm{~N}$ ) is the isotopic signal of the sample, $R_{s a}$ is the ${ }^{13} \mathrm{C} /{ }^{12} \mathrm{C}\left(\right.$ or $\left.{ }^{15} \mathrm{~N} /{ }^{14} \mathrm{~N}\right)$ ratio for the sample, $R_{s t}$ is the ${ }^{13} \mathrm{C} /{ }^{12} \mathrm{C}\left(\right.$ or $\left.{ }^{15} \mathrm{~N} /{ }^{14} \mathrm{~N}\right)$ ratio for the standard.

For ${ }^{13} \mathrm{C} /{ }^{12} \mathrm{C}$, the reference material is the carbonate from a fossil belemnite from Pee Dee Formation (Farquhar et al. 1989). For ${ }^{15} \mathrm{~N} /{ }^{14} \mathrm{~N}$, the standard is atmospheric $\mathrm{N}_{2}$ (Robinson 2001).

The soil samples were not treated with acid to remove the carbonates, because we wanted to analyze the total $\delta^{13} \mathrm{C}$ of the top soil, determined by organic and inorganic C.

\subsection{Estimative of the $\mathrm{C}$ stock}

The amount of $\mathrm{C}$ stored in the soil was estimated using the Eq. (2), modified from Guo and Gifford (2002):

$$
C_{s t}=C B D h,
$$

where $C_{s t}$ is the $\mathrm{C}$ stock $\left(\mathrm{t} \mathrm{ha}^{-1}\right), C$ is the $\mathrm{C}$ concentration $\left(\mathrm{g} \mathrm{kg}^{-1}\right), B D$ is the bulk density $\left(\mathrm{g} \mathrm{cm}^{-3}\right), h$ is the thickness of the surface soil, in centimeters (0-20).

As the gravels did not occur in our samples, such fraction was not here quantified. The values of $\mathrm{C}$ stock were corrected to soil mass according to procedures and equations cited in Poeplau et al. (2011).

\subsection{Statistical analyses}

Statistical parameters were calculated using the database as a whole. In addition, the arithmetic average was determined for each attribute separately for each land cover category. The Kruskal-Wallis test was used for each variable to check the level of significance of the differences among the land cover classes. Spearman correlation test was performed in order to check the correlation level among the variables $(\mathrm{P}=0.05)$.

The Fisher's linear discriminant analysis (F-LDA) was performed to check the similarity of the SP according to the land cover categories. The F-LDA is a statistical method that indicates which variables contribute most to group separation based on differences of the variables (Burns, R., Burns, R. 2008).

\section{Results}

\subsection{Soil attributes, influence of land cover on soil attributes and Fisher's discriminant analysis}

Sand, predominantly the coarse fraction, was major textural fraction for soils of the study area (Table 2). While the content of clay presented significant correlation only with other textural components of the soil, the silt fraction presented significant correlation with $\mathrm{BD}$ (direct correlation) and the sand fraction presented significant and inverse correlation with values of $\mathrm{BD}$ and $\delta^{13} \mathrm{C}$.

\begin{tabular}{|c|c|c|c|c|c|c|c|c|}
\hline Attributes & Min & $\operatorname{Max}$ & Range & $1^{\text {st }} \mathrm{Q}$ & Median & $3^{\text {rd }} \mathrm{Q}$ & Mean & $\mathrm{CV}(\%)$ \\
\hline Coarse sand fraction $\left(\mathrm{g} \mathrm{kg}^{-1}\right)$ & 135.0 & 567.7 & 432.8 & 259.7 & 366.2 & 418.7 & 342.9 & 30.2 \\
\hline Medium sand fraction $\left(\mathrm{g} \mathrm{kg}^{-1}\right)$ & 90.5 & 698.0 & 607.5 & 168.7 & 249.8 & 292.1 & 249.6 & 42.4 \\
\hline Fine sand fraction $\left(\mathrm{g} \mathrm{kg}^{-1}\right)$ & 28.8 & 432.2 & 403.5 & 92.5 & 134.5 & 183.0 & 157.4 & 57.1 \\
\hline Total sand fraction $\left(\mathrm{g} \mathrm{kg}^{-1}\right)$ & 584.5 & 924.3 & 339.8 & 678.9 & 746.8 & 821.6 & 749.9 & 12.3 \\
\hline Clay fraction $\left(\mathrm{g} \mathrm{kg}^{-1}\right)$ & 10.0 & 240.0 & 230.0 & 60.0 & 100.0 & 120.0 & 100.3 & 51.4 \\
\hline Silt fraction $\left(\mathrm{g} \mathrm{kg}^{-1}\right)$ & 13.0 & 315.5 & 302.5 & 93.4 & 144.1 & 199.8 & 149.8 & 48.0 \\
\hline Soil bulk density $\left(\mathrm{g} \mathrm{cm}^{-3}\right)$ & 0.64 & 1.90 & 1.26 & 1.26 & 1.49 & 1.64 & 1.42 & 22.1 \\
\hline $\mathrm{N}(\mathrm{g} / \mathrm{kg})$ & 0.1 & 3.3 & 3.2 & 0.5 & 1.0 & 1.8 & 1.2 & 73.4 \\
\hline $\mathrm{C}(\mathrm{g} / \mathrm{kg})$ & 0.3 & 39.4 & 39.1 & 6.4 & 13.8 & 21.1 & 15.1 & 71.6 \\
\hline $\mathrm{C}_{\text {stock }}\left(\mathrm{Mg} \mathrm{ha}^{-1}\right)$ & 0.8 & 75.4 & 74.7 & 14.4 & 32.3 & 52.3 & 33.3 & 68.1 \\
\hline$\delta^{13} \mathrm{C}(\%)$ & -26.7 & -15.9 & 10.8 & -22.8 & -20.1 & -18.4 & -20.8 & 15.8 \\
\hline$\delta^{15} \mathrm{~N}(\%)$ & 2.6 & 11.8 & 9.3 & 5.1 & 6.1 & 7.5 & 6.5 & 27.7 \\
\hline C:N ratio & 5.5 & 16.6 & 11.1 & 11.9 & 12.6 & 13.9 & 12.7 & 16.0 \\
\hline $\mathrm{pH}-\mathrm{H}_{2} \mathrm{O}$ & 4.9 & 7.6 & 2.7 & 5.7 & 6.2 & 6.7 & 6.2 & 10.5 \\
\hline Cation Exch. Cap. $\left(\mathrm{cmol} \mathrm{kg}^{-1}\right)$ & 22.5 & 233.3 & 210.8 & 48.9 & 76.9 & 120.0 & 89.8 & 62.8 \\
\hline Elect Conductivity $\left(\mu \mathrm{S} / \mathrm{cm}^{-1}\right)$ & 33.9 & 577.0 & 543.1 & 109.4 & 177.5 & 270.0 & 203.9 & 61.8 \\
\hline
\end{tabular}

Table 2. Summary statistics for studied attributes considering all samples $(\mathrm{N}=40)$ 
For the BD the overall mean and median values were highly similar, and the highest value was $1.90 \mathrm{~g} . \mathrm{cm}^{-3}$ (Table 2). Only one sample from woody site presented value higher than the overall mean. Most of the samples that presented values of $\mathrm{BD}$ higher than the value of the $3^{\text {rd }}$ quartile are from built-up lands. The BD values were significantly and inversely (negatively) correlated with both $\mathrm{C}$ and $\mathrm{N}$ amounts.

The values of the amounts of $\mathrm{C}$ and $\mathrm{N}$ were highly correlated, as well as the values of the concentration of $\mathrm{C}$ and stock of C. Only one sample collected in woody site presented value of $\mathrm{C}$ concentration lower than the overall mean value. Overall mean value and range of values of $\mathrm{pH}$ stated the slight acidity of the soils, regardless the class of the category of land cover. The $\mathrm{pH}$ was the variable with lowest coefficient of variation (10.5\%) and the mean and median values were identical.

Values of $\delta^{13} \mathrm{C}$ ranged from -26.7 to $-15.9 \%$. The values of the mean and median were similar, meaning that the data are equally divided around the mean. Based on the mean value, we can infer that the quality of the SOM in overall context of the study area is already modified. All samples presented positive values of $\delta^{15} \mathrm{~N}$ and more enriched than the standard (atmospheric air). The range of values of the $\delta^{15} \mathrm{~N}$ signature found in all samples, including that ones collected from wooded sites, suggested that the regional $\mathrm{N}$ cycle is not well conservative, because in a region where the cycle of the $\mathrm{N}$ is admittedly conservative, the values of $\delta^{15} \mathrm{~N}$ of the SOM are near of zero or even negative. An example is the soil from the non polluted forests located in Chile (Boeckx et al. 2005).

Most of the samples collected from wooded sites presented value of C:N lower than the overall mean, while all values of the SP collected from grassy sites were upper than the overall mean. The values of electrical conductivity (EC) ranged largely. The values of both cation exchange capacity and also EC presented high correlation with the amounts of $\mathrm{C}$ and $\mathrm{N}$ (Table 3). Usually in soils considered of good quality, the EC ranges between 200 and $1,200 \mu \mathrm{S} / \mathrm{cm}^{-1}$, and they are highly correlated with the salt concentration in the soil, being the inverse of electrical resistivity (Brady, Weil 2004). The lowest limit value of this proposed classification is close of overall mean value found here. In our study area, $45 \%$ of the samples showed values upper than $200 \mu \mathrm{S} / \mathrm{cm}^{-1}$.

From the ten variables here considered, eight presented some significant difference among the land cover categories (Table 4). For the values of BD, the mean values of the land cover classes built-up and bare area were approximately $38 \%$ higher than the mean value calculated for woody sites, being statistically different. For grassy areas the value was approximately $25 \%$ higher than the mean value of the reference area and insignificantly different from the others land cover classes.

Regarding the values of $\delta^{15} \mathrm{~N}$, we reported the tendency of the woody sites present lowest values, suggesting a SOM of better quality, while the samples from the class built-up presented the worse conditions (because of the highest values), although the values were statistically non different. For the $\mathrm{pH}$ values we reported, for sites from built-up category, the tendency of a slightly neutral when compared with the others land cover classes.

The soils from bare areas presented the highest mean value of $\mathrm{BD}$, as well as smallest amounts of $\mathrm{C}$ and $\mathrm{N}, \mathrm{C}$ stock and smallest value of EC. On the other hand, samples from grassy sites presented indicators slightly worse

Table 3. Spearman correlation matrix for soil attributes. Values in bold mean statistically significance at $\mathrm{P}=5 \%$

\begin{tabular}{|c|c|c|c|c|c|c|c|c|c|c|c|c|c|c|c|}
\hline Variables & Sand $_{\mathrm{m}}$ & Sand $_{c}$ & Sand $_{t}$ & Clay & Silt & $\mathrm{BD}$ & $\mathrm{N}$ & $\mathrm{C}$ & $\mathrm{C}_{\mathrm{st}}$ & ${ }^{13} \mathrm{C}$ & ${ }^{15} \mathrm{~N}$ & C:N & $\mathrm{pH}$ & EC & CEC \\
\hline $\operatorname{Sand}_{\mathrm{f}}$ & -0.45 & -0.49 & -0.06 & -0.10 & 0.13 & -0.07 & -0.27 & -0.25 & -0.30 & 0.06 & -0.24 & 0.06 & -0.09 & -0.04 & -0.08 \\
\hline Sand $_{m}$ & & 0.17 & 0.64 & -0.19 & -0.66 & -0.30 & 0.22 & 0.22 & 0.21 & -0.21 & -0.05 & -0.01 & 0.19 & 0.12 & 0.13 \\
\hline Sand $_{c}$ & & & 0.38 & -0.36 & -0.21 & 0.02 & 0.19 & 0.17 & 0.22 & -0.23 & 0.21 & -0.11 & 0.29 & 0.07 & 0.01 \\
\hline Sand $_{t}$ & & & & -0.64 & -0.82 & -0.35 & 0.12 & 0.12 & 0.12 & -0.31 & -0.24 & -0.06 & 0.26 & 0.12 & 0.13 \\
\hline Clay & & & & & 0.16 & -0.04 & 0.06 & 0.05 & 0.00 & 0.19 & 0.05 & 0.01 & -0.28 & 0.06 & 0.04 \\
\hline Silt & & & & & & 0.41 & -0.16 & -0.15 & -0.13 & 0.18 & 0.28 & -0.01 & -0.18 & -0.20 & -0.19 \\
\hline $\mathrm{BD}$ & & & & & & & -0.56 & -0.56 & -0.51 & 0.27 & 0.48 & -0.09 & 0.08 & -0.62 & -0.60 \\
\hline $\mathrm{N}$ & & & & & & & & 0.99 & 0.97 & -0.35 & -0.15 & 0.29 & 0.07 & 0.82 & 0.86 \\
\hline $\mathrm{C}$ & & & & & & & & & 0.97 & -0.33 & -0.17 & 0.36 & 0.06 & 0.81 & 0.86 \\
\hline $\mathrm{C}_{\mathrm{st}}$ & & & & & & & & & & -0.33 & -0.14 & 0.39 & 0.06 & 0.79 & 0.84 \\
\hline${ }^{13} \mathrm{C}$ & & & & & & & & & & & 0.02 & 0.19 & -0.02 & -0.40 & -0.39 \\
\hline${ }^{15} \mathrm{~N}$ & & & & & & & & & & & & -0.06 & 0.41 & -0.30 & -0.26 \\
\hline C:N & & & & & & & & & & & & & 0.06 & 0.23 & 0.27 \\
\hline $\mathrm{pH}$ & & & & & & & & & & & & & & 0.19 & 0.19 \\
\hline EC & & & & & & & & & & & & & & & 0.99 \\
\hline
\end{tabular}


Table 4. Soil attributes according to land cover classes $(\mathrm{N}=40)$. For each variable, different letters mean difference significant at $\mathrm{P}=5 \%$. Identical letters mean no significant difference among the classes at $\mathrm{P}=5 \%$

\begin{tabular}{|c|c|c|c|c|c|c|c|c|}
\hline \multirow{2}{*}{$\begin{array}{l}\text { Classes of land cover and number } \\
\text { of sampling points }\end{array}$} & \multicolumn{2}{|c|}{ Wooded (10) } & \multicolumn{2}{|c|}{ Grassy (9) } & \multicolumn{2}{|c|}{ Built Up (11) } & \multicolumn{2}{|c|}{ Bare Area (10) } \\
\hline & Mean & $\mathrm{CV}(\%)$ & Mean & CV (\%) & Mean & CV (\%) & Mean & $\mathrm{CV}(\%)$ \\
\hline $\mathrm{BD}\left(\mathrm{g} \mathrm{cm}^{-3}\right)$ & $1.13 \mathrm{a}$ & 25.0 & $1.43 \mathrm{ab}$ & 25.5 & $1.55 \mathrm{~b}$ & 14.6 & $1.56 \mathrm{~b}$ & 14.3 \\
\hline $\mathrm{N}\left(\mathrm{g} \mathrm{kg}^{-1}\right)$ & $2.2 \mathrm{~b}$ & 32.0 & $1.2 \mathrm{ab}$ & 56.2 & $0.8 \mathrm{a}$ & 67.0 & $0.5 \mathrm{a}$ & 94.6 \\
\hline $\mathrm{C}\left(\mathrm{g} \mathrm{kg}^{-1}\right)$ & $27.4 \mathrm{~b}$ & 28.2 & $16.8 \mathrm{ab}$ & 55.0 & $10.6 \mathrm{a}$ & 70.7 & $6.2 \mathrm{a}$ & 95.6 \\
\hline $\mathrm{C}_{\text {stock }}\left(\mathrm{Mg} \mathrm{ha}^{-1}\right)$ & $58.8 \mathrm{~b}$ & 19.1 & $37.9 \mathrm{ab}$ & 54.0 & $24.0 \mathrm{a}$ & 72.5 & $13.9 \mathrm{a}$ & 96.7 \\
\hline$\delta^{13} \mathrm{C}(\%)$ & $-25.2 \mathrm{a}$ & 6.2 & $-18.0 \mathrm{~b}$ & 7.3 & $-19.6 b$ & 11.0 & $-21.0 \mathrm{ab}$ & 11.5 \\
\hline$\delta^{15} \mathrm{~N}(\% 0)$ & $5.6 \mathrm{a}$ & 17.6 & $6.2 \mathrm{a}$ & 21.2 & $7.3 \mathrm{a}$ & 34.8 & $6.6 \mathrm{a}$ & 25.4 \\
\hline $\mathrm{C}: \mathrm{N}$ & $12.9 \mathrm{ab}$ & 10.3 & $14.1 \mathrm{~b}$ & 6.3 & $11.9 \mathrm{a}$ & 16.7 & $11.9 \mathrm{a}$ & 23.5 \\
\hline $\mathrm{pH}-\mathrm{H}_{2} \mathrm{O}$ & $6.1 \mathrm{a}$ & 8.1 & $6.1 \mathrm{a}$ & 9.6 & $6.6 \mathrm{a}$ & 10.7 & $6.1 \mathrm{a}$ & 12.4 \\
\hline Cation Exch. Cap. (cmol kg-1) & $144.6 \mathrm{~b}$ & 32.0 & $85.8 \mathrm{ab}$ & 70.5 & $83.4 \mathrm{ab}$ & 56.2 & $45.5 \mathrm{a}$ & 40.7 \\
\hline Elect. Conductivity $\left(\mu \mathrm{S} / \mathrm{cm}^{-1}\right)$ & $359.7 \mathrm{~b}$ & 31.7 & $186.1 \mathrm{ab}$ & 39.3 & $175.0 \mathrm{a}$ & 47.9 & $95.7 \mathrm{a}$ & 63.9 \\
\hline
\end{tabular}

than samples taken from reference sites (i.e., higher BD, lower $\mathrm{C}$ and $\mathrm{N}$ amounts, and lower EC), but not significantly different for almost all variables, excepting for $\delta^{13} \mathrm{C}$.

Also about the bare areas, for EC, although the values were statistically similar with the other land cover categories, we observe average value almost 50\% smaller than the mean value of reference, woody sites. Samples from built-up areas also presented mean values of soil attributes significantly different from the mean values of reference sites for the attributes $\mathrm{BD}, \mathrm{C}$ and $\mathrm{N}$ concentration, $\mathrm{C}$ stock and EC.

The diagram yielded through L-FDA (Fig. 2) confirms that soils under woody sites have characteristics different from the soils beneath anthropogenic categories of land cover. We note a region of SP overlapped in the regions that appear the SP collected in sites from humaninduced land cover categories.

The confusion matrix (Table 5) supports the showed difference, because no one SP from woody site was misclassified. The samples from grassy sites were mostly successfully differentiated (illustrated by the higher values

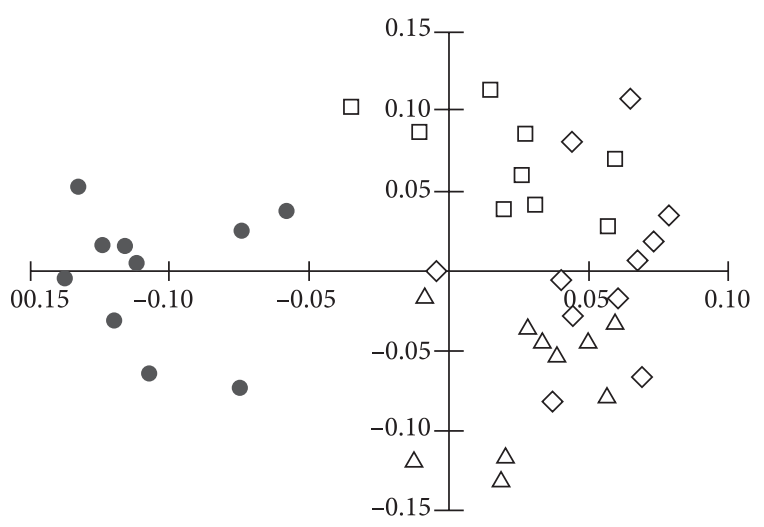

- Woody $\square$ Grass $\diamond$ Built up $\triangle$ Bare soil

Fig. 2. Scatter diagram of samples according to the sites of the four considered land cover categories of percentage) and they occupied a specific region of the diagram. Similar situation is observed for SP from bare areas, although the SP of such category occupied another region of the diagram. On they turn, SP from built-up lands occupied intermediary region of the diagram and a high level of confusion and misclassification (63.6\%) is observed. Hence, the overall mean percentage of success in the classification was $80.3 \%$.

Table 5. Confusion matrix for the estimation sample. The number in each cell corresponds to amount of samples that were correctly classified by the F-LDA

\begin{tabular}{lcccccc}
\hline from $\backslash$ to & $\begin{array}{c}\text { Wood- } \\
\text { land }\end{array}$ & $\begin{array}{c}\text { Grass- } \\
\text { land }\end{array}$ & $\begin{array}{c}\text { Built } \\
\text { up }\end{array}$ & $\begin{array}{c}\text { Bare } \\
\text { areas }\end{array}$ & Total & $\%$ correct \\
\hline Woodland & 10 & 0 & 0 & 0 & 10 & 100.0 \\
\hline Grassland & 1 & 7 & 1 & 0 & 9 & 77.8 \\
\hline Built up & 0 & 2 & 7 & 2 & 11 & 63.6 \\
\hline Bare areas & 0 & 0 & 2 & 8 & 10 & 80.0 \\
\hline Total & 11 & 9 & 10 & 10 & 40 & $\begin{array}{c}\text { (average) } \\
80.3\end{array}$ \\
\hline
\end{tabular}

\section{Discussion}

\subsection{Soil attributes and influence of land cover}

The $\mathrm{BD}$ is a measure of soil compaction and the soil compaction is commonly encountered in urban landscapes (De Kimpe, Morel 2000; Hagan et al. 2012). This trend is confirmed in our study. Land cover influenced critically the values of soil bulk density (BD). Increasing the $\mathrm{BD}$ means compress the soil and this alters some essential ecosystem services played by the soil, as water infiltration and storage capacity (Quraishi, Mouazen 2013). Maintaining the soil structure to mitigating the soil compaction is a critical ecological service required for both urban and agriculture soils. For a urbanized area, soil compaction for built-up and bare lands might be not especially critical to plant growth (root penetration), since usually we 
do not expect crop yield (like in agricultural areas), but alterations in infiltration capacity and disruption of soil aggregation are types of soil degradation that should be avoided because of the influence on infiltration of water into the soil profile and runoff generation (Gregory et al. 2006; Silva et al. 2013).

The fact of the significant inverse correlation among $\mathrm{BD}$ and both $\mathrm{C}$ and $\mathrm{N}$ strongly suggest that the alterations in the $\mathrm{BD}$ impacted the $\mathrm{C}$ and $\mathrm{N}$ concentrations, possibly because the reduction of the pore size, changing the dynamic of the $\mathrm{C}$ and $\mathrm{N}$ of the soil aggregates. This consequently reduces the water accessibility to microorganisms and reduces the capacity of storing $\mathrm{C}$ and $\mathrm{N}$ (Silva 2012; Silva et al. 2015a). The vegetation cover is a critical component that drives the $\mathrm{BD}$ and consequently the soil porosity (Jim 1998) and intensifying the arboreal cover in strategic locals is an important environmental service required as a part of the reengineering of the urban land cover design. For Latin America urban regions intensifying the arboreal cover is a mandatory activity, because the rate the migration of people from rural to urban regions is high (Grau, Aide 2008; WB 2014) and removing the vegetation due expansion of urban areas usually is an automatic consequence.

For soils under wooded sites, the average $\mathrm{C}$ stock estimated was $58.8 \mathrm{tha}^{-1}$ and for soils under grassy sites the average was $37.9 \mathrm{t} \mathrm{ha}^{-1}$. Comparatively, Silva et al. (2009) in a rural area of Sorocaba (approximately $20 \mathrm{~km}$ far from the area of this study) found in soils under wooded sites an average value of $55.6 \mathrm{t} \mathrm{ha}^{-1}$ of stored $\mathrm{C}$ and $28.9 \mathrm{t} \mathrm{ha}^{-1}$ in soils under grassy sites in this same farm. The crucial difference among the grassy lands is that in the farm occurred a mismanaged livestock, but not in the urbangrassy sites. The trampling of animals and the excessive grass consumption by the cattle prejudices the formation of a mulch layer, and the ground surface becomes unprotected, stimulating the $\mathrm{C}$ and $\mathrm{N}$ losses from the soil by oxidation of SOM and soil erosion (Silva et al. 2015b). Further, we show that soils under forest even surrounded by urban-related land cover categories and subjected to several kinds of external pressures, have the potential to stock $\mathrm{C}$ in quantities similar to forest fragments located in non urbanized regions and this is a critical property of the urban forests that must be exalted in terms of planning of urban landscapes. This higher value of stored $\mathrm{C}$ in urban sites agrees with the trend reported by Edmondson $e t$ al. (2012) who stated that the urban soils store significantly more $\mathrm{C}$ than arable soils.

Taking into account the mosaic of land cover here reported the overall weighted mean for entire watershed of C stored was $28.5 \mathrm{t} \mathrm{ha}^{-1}$. Considering the area of the watershed, the resulting value was 8,210.2 tons of C stored in the $20 \mathrm{~cm}$ topsoil for the entire watershed. This value was approximately $48.5 \%$ lower than the value considered, supposing that the area were entirely woody covered (16,934.4 tons) and interpreted as the maximum amount of $\mathrm{C}$ that the region is capable to store in the topsoil. Presuming that the watershed were entirely occupied exclusively by the built-up category (as the downtown of many medium- or big-sized cities), the value would be of $6,912.0$ tons, meaning $15.8 \%$ less than the value estimated for current scenario and $59.2 \%$ less if all watershed were totally forest-covered. These predicted results evidence once more the necessity of a correct urban design, in order to preserve some essential ecosystem services.

Soils have a propensity to be chemically altered when unfamiliar materials are applied to them and this usually increases the value of soil electrical conductivity (EC) (Seifi et al. 2010). On the other hand, other degrading processes, as soil erosion, trend to provoke the loss of nutrients and by consequence decreases the EC values (Moebius-Clune et al. 2011). Values of EC exceptionally low or extremely high might cause difficulties for plants increasing and survivor. In our study area we note an expressive diminution of EC values in SP from human-induced land cover categories comparing with values from reference area. Hence, while in urban soils an enrichment of the soil could be supposed due to possibility of a usual contamination, for our study area we detected that the trend is an impoverishment due mismanagement of the ground cover and a forced exposition of the soil to weathering.

The C:N ratio reflects the kind of material that is deposited on the ground surface and also its vulnerability for decomposition, and indicates how the nutrient cycles are regulated in the soil (Edmondson et al. 2014). The range of values of C:N in urban soils is usually high, because natural and anthropogenic organic particles might occur together (Lorenz, Lal 2009). In our study area, in the built-up and of bare soil sites, which are areas where we supposed that none kind material is added voluntarily (as solid wastes), the mean value of C:N was lower than in the soils underneath woody areas. For soils from grassy vegetation, where we have a constant deposition of materials richer in fiber, the $\mathrm{C}: \mathrm{N}$ is higher than in the woody sites. Comparatively, in a rural area approximately $60 \mathrm{~km}$ from Sorocaba, Silva et al. (2015b) found values of C:N of 14.4 in soils from organic farms and 14.3 in soils from conventional farms (in both there is plowing and addition of some kind of soil amendment), and both were discretely higher when compared with adjacent, forested soils.

Regarding the discrimination against the ${ }^{13} \mathrm{C}$ by some groups of plants, Vagen et al. (2006) suggest, for tropical soils whose value of $\delta^{13} \mathrm{C}$ is $<-19.5 \%$ the classification is $\mathrm{C}_{3}$, and for soils with values of $\delta^{13} \mathrm{C} \geq-19.5 \%$ they fall in the $\mathrm{C}_{4}$ group. Dividing our overall dataset according to this criterion, seventeen samples are classified as $\mathrm{C}_{3}$. No one sample taken in woody sites was classified as $\mathrm{C}_{4}$. One SP collected in a grass covered local was classified as $\mathrm{C}_{3}$, as 
well eight from the ten samples collected in bare areas. For the samples classified as $\mathrm{C}_{3}, 43 \%$ were taken from woody sites and only one sample from grassy ground. The overall average for study area is $-20.4 \%$, categorized as $\mathrm{C}_{3}$, indicating that although an important fraction of the land cover of the study is already altered, an important fraction of the original SOM still remains in the soil, even in soils with human-made classes of land cover.

Constant soil disturbances caused by human activities stimulate large losses of ${ }^{14} \mathrm{~N}$, leaving behind a ${ }^{15} \mathrm{~N}$ enriched residual (Boeckx et al. 2005). Although we noted the different categories of land cover did not produced significant difference in the $\delta^{15} \mathrm{~N}$ of the soils, the increasing in values of $\delta^{15} \mathrm{~N}$ and synchronized decreasing in the $\mathrm{N}$ concentration in the anthropogenic land cover classes states that after the disturbance, the regimen of loss of mineral $\mathrm{N}$ is intensified. Comparatively, while in our urbanized study site the enrichment of $\delta^{15} \mathrm{~N}$ was averaged in $20 \%$ for man-induced land covers in relation to reference sites, in rural areas (arable lands) in Ibiuna (SP, $60 \mathrm{~km}$ far from Sorocaba) the enrichment was averaged 38\% (Silva et al. 2015a), suggesting that in the rural area the $\mathrm{N}$ cycle is more opened than in our urbanized study area, because the usual high positive correlation among ${ }^{15} \mathrm{~N}$ enrichment of soil $\mathrm{N}$ and high humification of soil organic matter (Balieiro et al. 2012).

The $\mathrm{pH}$ is a determining factor for chemical reactions in the soil and the processes of soil acidification increment the mobility of some elements (Barrales et al. 2007). For our study area this attribute does not appear to be a concern, because of genetic reasons, the soil is naturally and slightly acidic and the differences in the land covers did not provoked significant alteration in the $\mathrm{pH}$. For another factor that supposed influence the soil $\mathrm{pH}$, the $\mathrm{pH}$ of the rainwater, Antunes et al. (2011) reported mean values of $\mathrm{pH}$ for rainwater of 6.6, classified as slightly acidic and typical for the region. Comparatively, low coefficient of variation of soil $\mathrm{pH}$ (12.8\%) was also observed by Pouyat et al. (2007) for urban soils in the City of Baltimore, Maryland, USA.

\subsection{Fisher's discriminant analyses and a complementary-integrative discussion}

Human-driven landscapes constitute a mosaic with many edges and cores and consequently, distinct sites with patterns of disturbance and management that will affect soil features through time. The result is a mosaic of soil patches with particular features changing according to the land cover categories (Pickett, Cadenasso 2009). This trend is observed for our study area and supported by the complete and clear separation of the SP collected in woody sites from the other ones resulted by FDA (Fig. 2).

In the Figure 2 we see that the data from the three anthropogenic land cover formed one group of points with partial overlapping. Comparatively Pouyat et al.
(2007), using soil data from different land cover categories and applying a statistical multivariate analysis, also show, in the scatter plot, a region where the soils under forested sites are concentrated in a separate region of the graphic, while the soils under human-induced land cover categories are not overlapped with forested sampling points, but highly overlapped among them. Hence, it seems that it is a common characteristic observed between urban regions from underdeveloped (Brazil, Latin America) and developed (USA) regions.

Changing land cover for urbanization creates hotspots for losses in carbon stocks. Conversely, such areas have potential to sequester and store $C$ when impervious surfaces in existing urbanized areas such as pavements, parking lots, public squares are substituted by vegetated surfaces (e.g., bricks with gaps between them that allow the growing of herbaceous plants with edaphic biomass stored in root system of the plants) to minimize the impacts of soil sealing on storing C) (Tao et al. 2014). In other words, we have a set of subjects to be considered in a project aiming a territorial reorganization.

The electrical conductivity (EC) is a useful environmental descriptor, since it permits an integrate analysis of the role of the soil and land cover as potential retainer or exporter of ions, enabling to establish a budget among the rate of input of ions (by means of analysis of EC of the rain water), the stored ions in the soil and output/exportation by the superficial river network (Silva 2012). Comparatively, for urban watersheds in USA, values of EC were 30 times higher in the river water than in the rain water (Pellerin et al. 2008). For a rural area in Ibiuna (Brazilian Southeastern region) Silva et al. (2015a) reported increasing of two times. For the watershed here studied the augmentation was approximately 10 times (Fig. 3).

For the region of our studied watershed, major ion deposited through rain water is the potassium (Antunes et al. 2011), while major ions in the soil are (decreasing order) calcium $>$ magnesium $>$ potassium, regardless the land covers (Urban 2011). The same order was reported in the river water (Urban et al. 2010). Even taking into accounting the effect of dumping of domestic sewage into

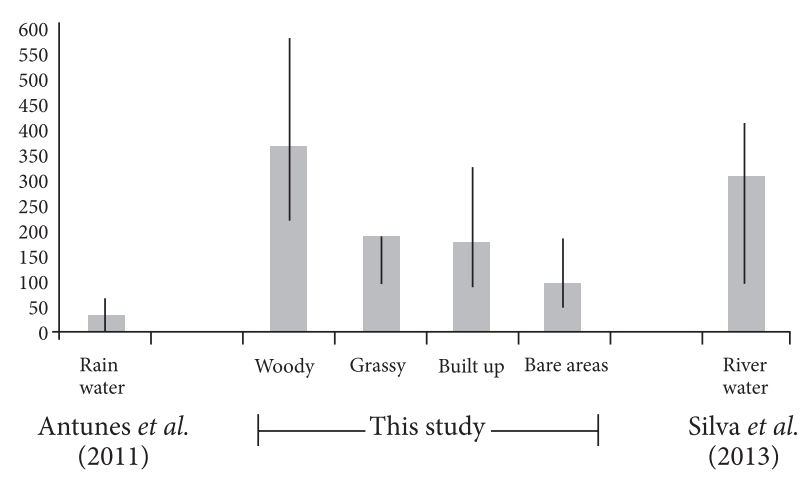

Fig. 3. Variation of values of electric conductivity (in $\mu \mathrm{S} / \mathrm{cm}^{-1}$ ) according to the compartments in study area 
the streams of the area here studied (Silva et al. 2013), when we compare the data of EC of the soil and river water, we can infer that fewer ions are transported from terrestrial to aquatic systems when we compare soil under forested regions with the other anthropogenic land cover categories.

Although there are a considerable number of contaminated sites in urbanized regions of Latin America, especially in Sao Paulo State (Brazil) and such contaminated areas are mostly related with problems of gas stations (www.cetesb.sp.gov.br), in most urbanized places from Latin America, the main source of contamination in soils seems to be vehicular traffic (López et al. 2006; Moura et al. 2006). Hence, the necessity of a correct design of urban zoning is once again highlighted, in order to reach the equilibrium between development and conservation.

The effects of increasing of urbanized areas are far to be completely elucidated, meaning that urban soils constitute an open frontier for environmental research (Vrscaj et al. 2008). Hence, other studies like this one should be carried out and reliable data should be systematically surveyed. One of the reasons is that the effect is highly variable according to geographic region (Edmondson et al. 2011; Hagan et al. 2012), the environmental characteristics of the region (Baltrenas et al. 2010; Templer et al. 2012), as well as the modality and intensity of urbanization (Alberti 2005; Boeckx et al. 2006).

The urbanization cannot be treated as an indomitable phenomenon. Researchers have detected, and we confirmed in this study, which the main problem is not the urbanization, but the urbanization incorrectly designed and/or executed (Alphan, Güvensoy 2016). This is especially true for many megacities. Projects of urban expansion incorrectly formulated and/or implemented diminish the buffer capacity and resilience of the local ecosystem, and they do not guarantee the environmental sustainability. Regarding soils and water bodies, keep suitable forested areas in adequate places is an important mechanism of avoiding chemical unbalances and disruptions in the ecosystems, either by enrichment (increasing in concentration of products and materials, meaning contamination) or impoverishment (leaching, erosion).

Controlling the pollution is a critical issue that should be considered in projects of urban expansion, in order to avoid the emanation of contaminated areas and water bodies. The maintenance of a suitable design of the land cover also is an imperative factor in terms of making the soil a strategic compartment of storing $\mathrm{C}$ and others elements or even making the soil a truly source of pollutants, with implications for global biogeochemical cycles.

Indeed, appropriate generation and use of information is one of the pillars for a successful sustainable urbanization process. For example, analyzing many urban regions in Latin America through the Google Earth
System (https://www.google.com/earth/), we clearly note a faint occurrence of forest patches in urban regions, as well as riparian vegetation along the river networks, and this appear to be a trend for urban regions of the continent, whatever is the size of the city.

Hence, projects considering re-vegetation of the riparian stretches (aiming to create riparian linear parks, for instance) should be prioritized in order to improve of the protection the water courses, incrementing the area forestcovered in the cities, improving the local climatic conditions, and contribute in the regulation of the $\mathrm{N}$ cycling in a watershed scale. In other words, the land use in urban regions needs to be more efficient, in order to let that the soil exerts, in fact, the ecosystem services and roles that the soils should exert. The data surveyed in study support this statement.

\section{Conclusions}

The urban-related land cover classes critically increased the soil bulk density and altered the quality of C of SOM. Urban-related land cover categories entail modifications that sometimes make the urban soils similar to soils from a rural region (for example soils under grassy sites). Other land cover categories produce specific features of urbanized regions (for example, soil beneath built-up regions).

The amount of $C$ stored in the layer $0-20 \mathrm{~cm}$ of the soil for the entire watershed is almost a half of the total potential of the watershed and forested patches stored C in similar amount in relation to forest patches from non urbanized regions. This confirms that urban soils of the studied area are able to contribute in storing $\mathrm{C}$ if a project of land cover development is adequately implemented. The scenario of the studied watershed is not better because of the poorly designed land cover currently existing. To improve such design, natural soils should be preserved in strategic places where urban growth encroaches into pristine areas and new forested areas should be created following some principles suggested by landscape ecologists aiming to get the landscape ecologically more functional (Antrop 2004).

For our study area, the values of electrical conductivity of the soils are augmented in approximately 10 times when they are compared values among rainfall and river waters. Forested sites are retainers of ions, while other sites with human-induced land cover classes are exporters.

Soils from urban settlements should not be ignored in regional and global $\mathrm{C}$ evaluations, highlighting the urgent need to extend the measurement of $\mathrm{C}$ stocks to other urbanized regions of the Latin America. The maintenance or recovering of the soil quality is an issue that should be considered as priority in a process of (re)engineering of the territorial organization, in order to help mitigating the degrading effects of the (disorganized) urbanization. 


\section{Acknowledgements}

This work was partially supported by the Brazilian agencies FAPESP (under grant number 2009/02182-3) and CAPES (grant number not provided).

\section{References}

Alberti, M. 2005. The effects of urban patterns on ecosystem function, International Regional Science Review 28: 168-192. https://doi.org/10.1177/0160017605275160

Alphan, H.; Güvensoy, L. 2016. Detecting coastal urbanization and land use change in Southern Turkey, Journal of Environmental Engineering and Landscape Management 24: 97-107. https://doi.org/10.3846/16486897.2015.1113976

Anderson, J. R. 1976. A land use and land cover classification system for use with remote sensor data, Vol. 964. US Government Printing Office.

Antrop, M. 2004. Landscape change and the urbanization process in Europe, Landscape and Urban Planning 67(1-4): 9-26. https://doi.org/10.1016/S0169-2046(03)00026-4

Antunes, M. L. P.; Antunes, R. H.; Fornaro, A.; Astolfo, R. 2011. Composição química da água de chuva e deposição atmosférica na cidade de Sorocaba (SP), in $26^{\text {th }}$ Brazilian Congress of Environmental and Sanitation Engineering, 2011, Porto Alegre Rio Grande do Sul, Brazil.

Balieiro, F. D. C.; Benites, V. D. M.; Caiafa, A. N.; Alves, B. J. R.; Fontana, A.; Canellas, L. P. 2012. Vegetation influence on organic matter source of black soils from high altitude rocky complexes traced by ${ }^{13} \mathrm{C}$ and ${ }^{15} \mathrm{~N}$ isotopic techniques, Catena 99: 97-101. https://doi.org/10.1016/j.catena.2012.06.004

Baltrenas, P.; Pranskevičius, M.; Lietuvninkas, A. 2010. Investigation and assessment of dependences of the total carbon on $\mathrm{pH}$ in Neris regional park soil, Journal of Environmental Engineering and Landscape Management 18: 179-187. https://doi.org/10.3846/jeelm.2010.21

Barrales, C. C.; Bauer, L. I.; Santos, A. T.; González, R. C. 2007. Cadmio, plomo, níquel y zinc en suelos del Parque Desierto de los Leones, Terra Latinoamericana 25: 95-103.

Boeckx, P.; Meirvenne, M. van; Raulo, F.; Cleemput, O. 2006. Spatial patterns of $\delta^{13} \mathrm{C}$ and $\delta^{15} \mathrm{~N}$ in the urban topsoil of Gent, Belgium, Organic Geochemistry 37: 1383-1393. https://doi.org/10.1016/j.orggeochem.2006.04.015

Boeckx, P.; Paulino, L.; Oyarzun, C.; Cleemput, O.; Godoy, R. 2005. Soil $\delta^{15} \mathrm{~N}$ patterns in old-growth forests of southern Chile as integrator for $\mathrm{N}$-cycling, Isotopes in Environmental and Health Studies 41: 249-259.

https://doi.org/10.1080/10256010500230171

Brady, N. C.; Weil, R. R. 2004. Elements of the nature and properties of soils. New Jersey, USA: Prentice Hall.

Burns, R.; Burns, R. 2008 Business research methods and statistics using SPSS. Extra chapter (number 25: Discriminant Analysis) [online], [cited 25 April 2013]. Sage Pub. Available from Internet: http://www.uk.sagepub.com/burns/website\%20material/Chapter\%2025\%20-\%20Discriminant\%20Analysis.pdf

De Kimpe, C. R.; Morel, J. L. 2000. Urban soil management: a growing concern, Soil Science 165: 31-40. https://doi.org/10.1097/00010694-200001000-00005

Edmondson, J. L.; Davies, Z. G.; Gaston, K. J.; Leake, J. R. 2014. Urban cultivation in allotments maintains soil qualities adversely affected by conventional agriculture, Journal of Applied Ecology 51: 880-889.

https://doi.org/10.1111/1365-2664.12254

Edmondson, J. L.; Davies, Z. G.; McCormack, S. A.; Gaston, K. J., Leake, J. R. 2011. Are soils in urban ecosystems compacted? A citywide analysis, Biology Letters 7: 771-774. https://doi.org/10.1098/rsbl.2011.0260

Edmondson, J. L.; Davies, Z. G.; McHugh, N.; Gaston, K. J.; Leake, J. R. 2012. Organic carbon hidden in urban ecosystems, Scientific Reports 2. https://doi.org/10.1038/srep00963

Farquhar, G. D.; Ehleringer, J. R.; Hubick, K. T. 1989. Carbon isotope discrimination and photosynthesis, Annual Review of Plant Physiology 40: 503-537.

https://doi.org/10.1146/annurev.pp.40.060189.002443

Grau, H. R.; Aide, M. 2008. Globalization and land-use transitions in Latin America, Ecology and Society 13(2): 16 [online], [cited 23 September 2014] URL: http://www.ecologyandsociety.org/vol13/iss2/art16

Gregory, J. H.; Dukes, M. D.; Jones, P. H.; Miller, G. L. 2006. Effect of urban soil compaction on infiltration rate, Journal of Soil and Water Conservation 61: 117-124.

Guo, L. B.; Gifford, R. M. 2002. Soil carbon stocks and land use change: a meta-analysis, Global Change Biology 8: 345-360. https://doi.org/10.1046/j.1354-1013.2002.00486.x

Hagan, D.; Dobbs, C.; Timilsina, N.; Escobedo, F.; Toor, G. S.; Andreu, M. 2012. Anthropogenic effects on the physical and chemical properties of subtropical coastal urban soils, Soil Use and Management 28: 78-88. https://doi.org/10.1111/j.1475-2743.2011.00379.x

IBGE. 2013. Cidades [online], [cited 15 January 2015]. Federal Brazilian Institute for Geography and Statistics, Rio de Janeiro. Available from Internet: http://www.cidades.ibge.gov.br/ xtras/home.php

IGSP. 2009. Geological map of Sorocaba Municipality: Report. Scale: 1:50,000. Geological Institute of São Paulo State. 59 p. (in Portuguese).

Jim, C. Y. 1998. Urban soil characteristics and limitations for landscape planting in Hong Kong, Landscape and Urban Planning 40: 235-249. https://doi.org/10.1016/S0169-2046(97)00117-5

Kahan, A. Y. 2008. Nitrogen and Carbon biogeochemistry in soil and vegetation along an indirect urban-rural gradient in southeastern Michigan: Dissertation. University of Michigan.

Kaye, J. P.; Groffman, P. M.; Grimm, N. B.; Baker, L. A.; Pouyat, R. V. 2006. A distinct urban biogeochemistry? Trends in Ecology and Evolution 21: 192-199. https://doi.org/10.1016/j.tree.2005.12.006

Kronka, F. J. N. et al. 2005. Monitoramento da vegetação natural e do reflorestamento no estado de São Paulo, in Proceedings of XII Brazilian Symposia of Remote Sensing, Goiânia, Goiás, Brazil, 1569-1576.

López, S. C.; Perelman, P. E.; Rivara, M.; Castro, M. A.; Faggi, A. 2006. Características del suelo y concentración de metales a lo largo de un gradiente de urbanización en Buenos Aires, Argentina, Multequina 15: 69-80.

Lorenz, K.; Lal, R. 2009. Biogeochemical C and N cycles in urban soils, Environment International 35: 1-8. https://doi.org/10.1016/j.envint.2008.05.006

Melfi, A. J.; Montes, C. R.; Carvalho, A.; Forti, M. C. 2004. Use of pedological maps in the identification of sensitivity of soils 
to acidic deposition: application to Brazilian soils, Annals of Brazilian Academy of Sciences 76: 139-145. https://doi.org/10.1590/S0001-37652004000100012

Moebius-Clune, B. N.; van Es, H. M.; Idowu, O. J.; Schindelbeck, R. R.; Kimetu, J. M.; Ngoze, S.; Lehmann, J.; Kinyangi, J. M. 2011. Long-term soil quality degradation along a cultivation chronosequence in western Kenya, Agriculture, Ecosystems and Environment 141: 86-99. https://doi.org/10.1016/j.agee.2011.02.018

Morgan, R. P. C. 2009. Soil erosion and conservation. John Wiley \& Sons.

Moura, M. C. S.; Lopes, A. N. C.; Moita, G. C.; Neto, J. M. M. 2006. Estudo multivariado de solos urbanos da cidade de Teresina, Química Nova 29: 429-435. https://doi.org/10.1590/S0100-40422006000300005

Norra, S.; Handley, L. L.; Berner, Z.; Stüben, D. $2005 .{ }^{13} \mathrm{C}$ and ${ }^{15} \mathrm{~N}$ natural abundances of urban soils and herbaceous vegetation in Karlsruhe, Germany, European Journal of Soil Sciences 56: 607-620. https://doi.org/10.1111/j.1365-2389.2005.00701.x

Pellerin, B. A. et al. 2008. The application of electrical conductivity as a tracer for hydrograph separation in urban catchments, Hydrological Processes 22: 1810-1818. https://doi.org/10.1002/hyp.6786

Pickett, S. T. A.; Cadenasso, M. L. 2009. Altered resources, disturbance, and heterogeneity: a framework for comparing urban and non-urban soils, Urban Ecosystems 12: 23-44. https://doi.org/10.1007/s11252-008-0047-x

Poeplau, C.; Don, A.; Vesterdal, L.; Leifeld, J.; Van Wesemael, B. A. S.; Schumacher, J.; Gensior, A. 2011. Temporal dynamics of soil organic carbon after land use change in the temperate zone-carbon response functions as a model approach, Global Change Biology 17: 2415-2427. https://doi. org/10.1111/j.1365-2486.2011.02408.x

Pouyat, R. V.; Groffman, P.; Yesilonis, I. D.; Hernandez, L. 2002. Soil carbon pools and fluxes in urban ecosystems, Environment Pollution 116: 107-118. https://doi.org/10.1016/S0269-7491(01)00263-9

Pouyat, R. V.; Yesilonis, I. D.; Nowak, D. J. 2006. Carbon storage by urban soils in the United States, Journal of Environmental Quality 35: 1566-1575.

Pouyat, R. V.; Yesilonis, I. D.; Russell-Anelli, J.; Neerchal, N. K. 2007. Soil chemical and physical properties that differentiate urban land-use and cover types, Soil Science Society of America Journal 71: 1010-1019. https://doi.org/10.2136/sssaj2006.0164

Quraishi, M. Z.; Mouazen, A. M. 2013. A prototype sensor for the assessment of soil bulk density, Soil and Tillage Research 134: 97-110. https://doi.org/10.1016/j.still.2013.07.011

Raij, B.; Andrade, J. C.; Cantarella, H.; Aquaggio, J. A. 2001. Análise química para avaliação da fertilidade de solos tropicais. Instituto Agronômico de Campinas, Campinas. 284 p.

Robinson, D. 2001. $\mathrm{d}^{15} \mathrm{~N}$ as an integrator of the nitrogen cycle, Trends in Ecology and Evolution 16: 153-162. https://doi.org/10.1016/S0169-5347(00)02098-X

Ruggiero, P. G. C.; Batalha, B. A.; Pivello, V. R.; Meirelles, S. T. 2002. Soil vegetation relationships (Brazilian savannah) and semi deciduous forest, Southeastern Brazil, Plant Ecology 160: 1-16. https://doi.org/10.1023/A:1015819219386

Saritha, V.; Vuppala, N. S.; Prashanthi, K.; Anjum, A. 2014. Soil properties governed by Municipal Solid Waste-Contemporary and enduring, Agriculture and Soil Sciences 1: 42-49.
Scalenghe, R.; Marsan, F. A. 2009. The anthropogenic sealing of soils in urban areas, Landscape and Urban Planning 90: 1-10. https://doi.org/10.1016/j.landurbplan.2008.10.011

Scharenbroch, B. C.; Lloyd, J. E.; Johnson-Maynard, J. L. 2005. Distinguishing urban soils with physical, chemical, and biological properties, Pedobiologia 49: 283-296. https://doi.org/10.1016/j.pedobi.2004.12.002

Seifi, M. R.; Alimardani, R.; Sharifi, A. 2010. How can soil electrical conductivity measurements control soil pollution?. Research Journal of Environ Earth Science 2: 235-238.

Silva, A. M. 2012. Efeito da mudança da cobertura da terra para fins de urbanização na quantidade e qualidade do $\mathrm{C}$ e do $\mathrm{N}$ da faixa superficial dos solos de uma microbacia em SorocabaSP: Habilitation for Adjunct Professor Thesis. São Paulo State University.

Silva, A. M.; Manfre, L. A.; Monteiro, T.; Moreira, M. Z.; Livingston, S.; Ducatti, C.; Brossard, M.; Sobral, A. C.; Urban, R. C. 2015a. Vulnerability of soil and its associated organic matter to degradation in a subtropical region: A study from São Paulo State, Brazil, Environmental Quality Management 24: 65-90. https://doi.org/10.1002/tqem.21402

Silva, A. M.; Manfre, L. A.; Urban, R. C.; Silva, V. H. O.; Manzatto, M. P.; Norton, L. D. 2015b. Organic farm does not improve neither soil, or water quality in rural watersheds from southeastern Brazil, Ecological Indicators 48: 132-146. https://doi.org/10.1016/j.ecolind.2014.07.044

Silva, A. M.; Nogueira, D. P.; Ikematsu, P.; Silveira, F. M.; Bomback, M.; Alves, S. H.; Paula, F. P.; Camargo, P. B. 2009. Carbon stocks and isotopic composition of the organic matter in soils covered by native vegetation and pasture in Sorocaba, SP, Brazil, International Journal Environmental Research 3: 435-440.

Silva, A. M.; Santos, A. R.; Fernandes, R. A.; Urban, R. C.; Carvalho, R. M.; Manfre, L. A.; Durrant, S. F. 2013. Hydrosedimentologic imbalance in an urbanized watershed, Acta Limnologica Brasiliensia 25: 140-149. https://doi.org/10.1590/S2179-975X2013000200005

Tao, Y.; Li, F.; Wang, R.; Zhao, D. 2014. Effects of land use and cover change on terrestrial carbon stocks in urbanized areas: a study from Changzhou, China, Journal of Clean Production 103: 651-657. https://doi.org/10.1016/j.jclepro.2014.07.055

Templer, T. H. et al. 2012. Sinks for nitrogen inputs in terrestrial ecosystems: a meta-analysis of ${ }^{15} \mathrm{~N}$ tracer field studies, Ecology 93: 1816-1829. https://doi.org/10.1890/11-1146.1

United Nations (UN). 2014. World Urbanization Prospects (highlights) [online], [cited 3 July 2014]. Available from Internet: http://esa.un.org/unpd/wup/Highlights/WUP2014-Highlights.pdf

Urban, R. C. 2011. Análise da relação entre a qualidade do solo, a qualidade da água e a fragilidade ambiental de uma microbacia de ocupação urbana crescente com relictos de vegetação natural localizada em Sorocaba - SP: Dissertation. São Paulo State University.

Urban, R. C.; Silva, A. M.; Manfré, L. A. 2010. Ionic condition and input and output rates of some chemical solutes in Lavapés stream, Sorocaba, SP, Brazil, Revista Ambiente \& Água 5: 265-277 (in Portuguese). https://doi.org/10.4136/ambi-agua.168

Vagen, T. G.; Walsh, M. G.; Sheperd, K. D. 2006. Stable isotopes for characterization of trends in soil carbon following deforestation and land use change in the highlands of Madagascar, Geoderma 135: 133-139. https://doi.org/10.1016/j.geoderma.2005.11.012 
Vasenev, V. I.; Stoorvogel, J. J.; Vasenev, I. I. 2013. Urban soil organic carbon and its spatial heterogeneity in comparison with natural and agricultural areas in the Moscow region, Catena 107: 97-102. https://doi.org/10.1016/j.catena.2013.02.009

Vela Correa, G.; López Blanco, J.; Rodríguez Gamiño, M. D. L. 2012. Niveles de carbono orgánico total en el Suelo de Conservación del Distrito Federal, centro de México, Investigaciones geográficas 77: 18-30.

Vrscaj, B.; Poggio, L.; Marsan, F. A. 2008. A method for soil environmental quality evaluation for management and planning in urban areas, Landscape and Urban Planning 88: 81-94. https://doi.org/10.1016/j.landurbplan.2008.08.005

Wang, Z.; Cui, X.; Yin, S.; Shen, G.; Han, Y.; Liu, C. 2013. Characteristics of carbon storage in Shanghai's urban forest, Chinese Science Bulletin 58: 1130-1138. https://doi.org/10.1007/s11434-012-5443-1

World Bank (WB). 2014. World databank indicators [online], [cited 5 June 2014]. Available from Internet: http://data. worldbank.org/indicator

Alexandre Marco da SILVA. Department of Environmental Engineering - Campus Sorocaba - São Paulo State University, Av. Três de Março, 511. Sorocaba - SP - Brazil.

Doctor. Professor at Campus of Sorocaba - Unesp. 64 published papers. Distinguished scholar of the Brazilian Council for Research and Technology (CNPq).

Rodrigo Custodio URBAN. Department of Sanitation and Environment - FEC - Campinas State University, Av. Albert Einstein, 951, Campinas - SP - Brazil. Doctor in Civil Engineering. Professor at Pontific Catholic University (Campinas, SP Brazil). He has 10 published papers.

Luiz Augusto MANFRÉ. Geoprocessing Laboratory - Polytechnic School - University of São Paulo - Avenue Professor Luciano Gualberto, Lane 3, 380, São Paulo, Brazil. Doctor in Civil Engineering. He has 13 published papers.

Michel BROSSARD. IRD, UMR 210 Eco\&Sols, BP 64501, 34394 Montpellier cedex 5, France.

Doctor. Researcher IRD Montpelier - France. 53 published papers.

Marcelo Zacharias MOREIRA. Centre for Nuclear Energy in Agriculture (CENA - USP) - University of São Paulo, Av. Centenário, 303 - Piracicaba, SP, Brazil. Professor at CENA - USP, Piracicaba, SP, Brazil. He has currently 54 published papers. 